\title{
Factor VIII related antigen positive macrophages and acquired immune deficiency syndrome (AIDS): a problem of antibody specificity
}

\author{
P R MillaRD*, A J CHAPLiN*. A R HERYET*, A C McDOUGALL \\ From the Departments of *Histopathology and Dermatology, John Radcliffe Hospital, Oxford
}

SUMMARY A further histopathological complication of atypical mycobacterial infection in acquired immune deficiency syndrome (AIDS) is reported. Positive reactivity between mycobacterial antibodies within a polyclonal antiserum and mycobacteria within tissues resulted in false positivity with this reagent to factor VIII related antigen. This complication may be avoided either by prior testing of the antiserum, or by purification, or by the use of monoclonal antibodies. Histopathologists examining tissues from patients with AIDS and those with disseminated mycobacterial infections and using immunohistochemical techniques should be aware of this occurrence.

Infection with mycobacteria, particularly those of the atypical Mycobacterium intracellularis complex, is a hazard for the patient with acquired immune deficiency syndrome (AIDS). ${ }^{12}$ Recognition of these organisms depends primarily on culture and also on showing the presence of the acid fast organisms using the Ziehl-Neelsen technique. Characteristic granulomatous changes are not always evident, ${ }^{3}$ and if the organism's presence is not realised confusion with Whipple's disease can occur. ${ }^{45}$ Further difficulty in interpreting the tissue features might arise if immunohistochemical reagents are used, as false positivity between some of these reagents and acid fast bacilli can occur. ${ }^{6}$ Such reactions were found in skin biopsy specimens from patients with leprosy when exposed to polyclonal antibodies to lysozyme, $\alpha_{1}$-antitrypsin, cytokeratins, myoglobulin, S100, and factor VIII. It was further shown that the positivity arose from the use of both Freund's complete adjuvant and human serum in the preparation of these antibodies. A similar circumstance, although in a patient with AIDS, is now reported.

\section{Case report}

The patient was a 39 year old homosexual who had lived for 18 years in the United States, predominantly New York and Boston. During 1981 he had had thoracic zoster followed by fatigue and weight loss. In

Accepted for publication 18 September 1986
April 1982 a transbronchial lung biopsy specimen included Pneumocystis carinii for which he received co-trimoxazole. At that time he had Kaposi's sarcoma on each ankle which was treated with irradiation.

Headaches with left visual difficulty, generalised weakness, and a wide-based gait developed in mid 1982. He also had diarrhoea associated with Entamoeba histolytica and Giardia lamblia and hepatitis due to cytomegalovirus (HBsAg negative). A month later he relapsed into semi-coma. A computed tomography brain scan showed nine space occupying lesions and a biopsy specimen identified Toxoplasma gondii. He was treated with sulphadiazine, pyrimethamine, and folinic acid and steroids. The Kaposi's sarcoma had become disseminated to his stomach and colon. He was able to walk out of the hospital in November 1982 but was leucopenic (white cell count $\left.<2 \times 10^{9} / 1\right)$. A few weeks later he relapsed with coma and a left sided weakness. Computed tomography brain scans showed further lesions, although a second brain biopsy specimen was negative for Toxoplasma. A full dose of antitoxoplasma treatment was given and his white cell count fell once again.

On his return to the United Kingdom he was unable to speak but could understand simple commands. He was gaunt and wasted with a left sided hemiparesis and athetoid movements of the right upper limb and trunk. He had Kaposi's sarcoma over his left thigh, anterior abdomen, lower back, and inside the pinna of his left ear. He had perianal herpetic ulcers and oral candidiasis. Axillary and femoral lymphadenopathy was present. He continued to 
Table 1 Summary of histopathology findings

\begin{tabular}{|c|c|c|}
\hline Kaposi's sarcoma & Acid fast bacilli & $\begin{array}{l}\text { Cytomegalovirus } \\
\text { inclusions }\end{array}$ \\
\hline $\begin{array}{l}\text { Skin } \\
\text { Tongue } \\
\text { Oropharynx } \\
\text { Oesophagus } \\
\text { Lung } \\
\text { Lymph node: } \\
\text { Mesenteric } \\
\text { Rectum }\end{array}$ & $\begin{array}{l}\text { Pituitary } \\
\text { Lymph nodes: } \\
\text { Mediastinal } \\
\text { Mesenteric } \\
\text { Liver } \\
\text { Spleen }\end{array}$ & $\begin{array}{l}\text { Brain } \\
\text { Salivary gland } \\
\text { Thyroid } \\
\text { Lung } \\
\text { Pancreas } \\
\text { Liver } \\
\text { Adrenal } \\
\text { Lymph node: } \\
\text { Mesenteric } \\
\text { Rectum }\end{array}$ \\
\hline
\end{tabular}

take the antitoxoplasma treatment-nystatin, benztropine, and barbiturate, but failed to improve and died in January 1983.

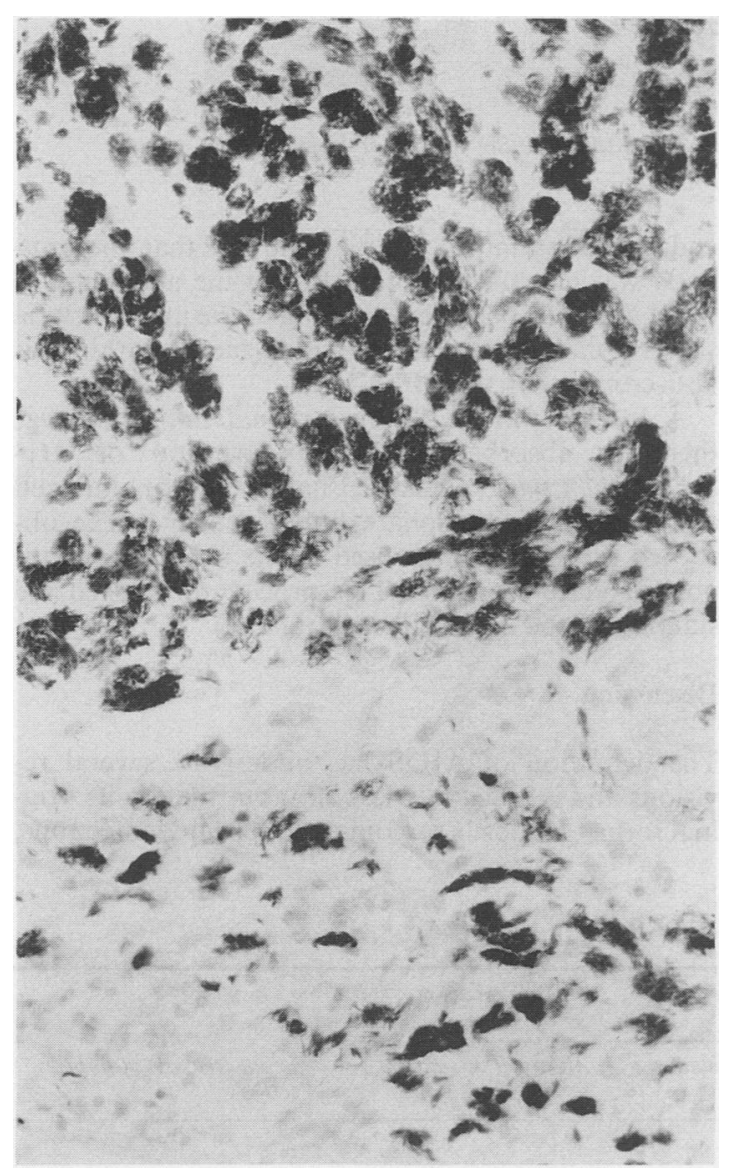

Fig 1 Mesenteric lymph node: macrophages filled with acid fast organisms. (Ziehl-Neelsen) $\times 240$.

\section{Pathology}

At necropsy the body was extremely wasted. The skin lesions included the characteristic features of Kaposi's sarcoma, and comparable tumour was found in other organs (table 1). The mesenteric lymph nodes were enlarged but not matted and had a fairly uniform yellow-white parenchyma. Most were totally replaced by large cells containing granular periodic acid Schiff-diastase positive material among which were Gram positive bacilli, staining positively in Ziehl-Neelsen preparations (fig 1). Similar features occurred in other tissues (table 1). No cultures for mycobacteria were made from any of these tissues.

Within the brain was focal cortical necrosis and also bilateral yellow striate necrosis of the basal ganglia extending into the ventricles. Neither Toxoplasma cysts nor tachyzoites were recognised. Findings in other tissues included cytomegaloviral inclusions (table 1), oesophageal ulceration with fungal hyphae, and sterile bronchopneumonic foci. Hassall's corpuscles were atrophic.

\section{Methods}

All tissues were fixed in $10 \%$ formol saline, and $5 \mu \mathrm{m}$ paraffin sections were stained with haematoxylin and eosin. Selected sections were also studied for microorganisms using the Ziehl-Neelsen procedure, Gram, periodic acid Schiff and Grocott stains (fig 1). Muramidase, $\alpha_{1}$-antitrypsin, factor VIII related antigen (FVIIIRA) (all from Hoechst) and human chorionic gonadotrophine (Miles), acting as a control, were looked for using an indirect immunoperoxidase method. This entailed the use of peroxidase conjugated swine antirabbit serum (Dakopatts, Dako Ltd) at $1 / 50$. Other controls, replacing the primary antiserum with non-immune serum, were done. The lymph nodes were also examined for non-specific esterase using $\alpha$-naphthyl acetate.

The cells including mycobacteria (table 1), stained positively for muramidase, non-specific esterase, $\alpha_{1}$-antitrypsin, and also FVIIIRA (fig 2 ). The sections of lymph node were studied further.

Immunoperoxidase staining using an indirect sandwich technique was repeated with the FVIIIRA (lot No 105710F) (table 2) and with three other antisera directed against FVIIIRA: a further sample from Hoechst (lot No 105712C) (table 2) and two samples, (lots 042C and 115 from Dakopatts, Dako Ltd). All primary antisera were diluted $1 / 100$. Endogenous peroxidase was blocked using hydrogen peroxide in methanol, and sections were pretreated with $0.1 \%$ trypsin in $0.1 \%$ calcium chloride, $\mathrm{pH} 7 \cdot 8$, for 30 minutes at $37^{\circ} \mathrm{C}$. Peroxidase labelling was visualised using $3,4,3^{\prime}, 4^{\prime}$-tetra-aminobiphenyl hydrochloride. 


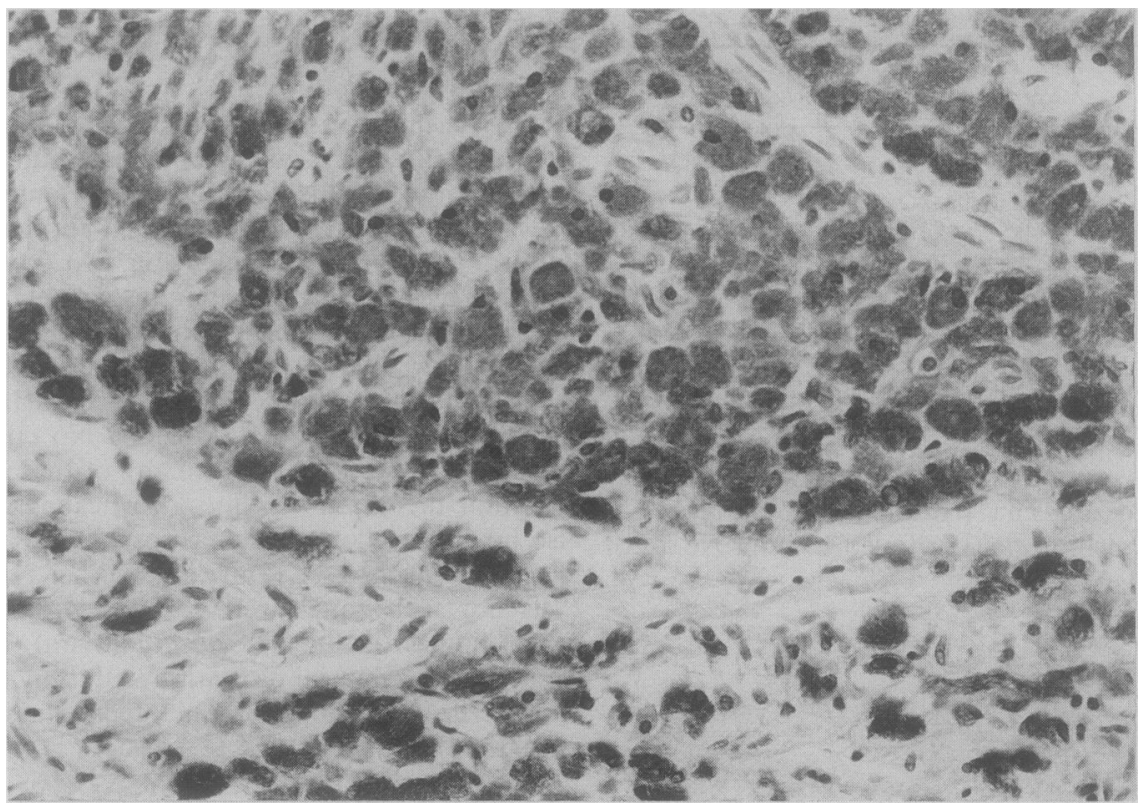

Fig 2 Mesenteric lymph node: same node as in fig 1 with positive staining for factor VIII related antigen. (Immunoperoxidase.) $\times 240$.

Substitution of the primary antibody with $1 / 10$ normal swine serum served as a negative control. There was staining of the vascular endothelium of some vessels with all four antisera but only of the organisms within the macrophages with the original antiserum (Hoechst lot No 105710F).

Affinity purification of the Hoechst antiserum (lot No $105710 \mathrm{~F}$ ) was carried out by absorption of this antiserum on to purified FVIIIRA (provided by Dr MJ Allington) conjugated to cyanogen bromide activated Sepharose (CN Br Sepharose), followed by elution of bound antibody using $\mathrm{pH} 2.5$ glycine buffer and neutralisation of the eluate with $0.5 \mathrm{M}$ Tris. Both the absorbed and eluted sera were then used for immunoperoxidase staining. Affinity purification of the antiserum using cyanogen bromide activated Sepharose conjugated with bovine serum albumin (BSA) was done in parallel as a means of control. The pattern of endothelial staining (table 2) showed that the antibody was effectively removed from the antiserum to the eluate. The persistent staining of the mycobacteria showed that there was a staining factor within this antiserum other than FVIIIRA.

A further sample of the original antiserum was therefore absorbed with a suspension of $M y$ cobacterium tuberculosis that had been formalin fixed and washed in phosphate buffered saline. The absorbed serum was then used in the standard immunoperoxidase sequence. This procedure blocked the staining of the mycobacteria (table 2).

\section{Discussion}

The definition of AIDS has undergone several revisions and is inevitably less clear cut than in its original form. ${ }^{7}$ Kaposi's sarcoma and repeated infections,

Table 2 Immunoperoxidase staining with FVIIIRA

\begin{tabular}{|c|c|c|c|c|c|c|c|}
\hline \multirow[t]{2}{*}{. } & \multirow[b]{2}{*}{${ }_{1}^{F V I I I R A}{ }_{3}$} & \multirow[b]{2}{*}{4} & \multicolumn{2}{|c|}{$\begin{array}{l}\text { CNBr Sepharose } \\
+ \text { FVIIIRA }\end{array}$} & \multicolumn{2}{|c|}{$\begin{array}{l}\text { CNBr Sepharose } \\
+B S A\end{array}$} & \multirow[b]{2}{*}{$\begin{array}{l}M \text { tuberculosis absorbed } \\
\text { serum }\end{array}$} \\
\hline & & & $\begin{array}{l}\text { Absorbed } \\
\text { serum }\end{array}$ & Eluate & $\begin{array}{l}\text { Absorbed } \\
\text { serum }\end{array}$ & Eluate & \\
\hline Vascular endothelium & +++ & + & - & + & + & - & + \\
\hline $\begin{array}{l}\text { Macrophages with } \\
\text { mycobacteria }\end{array}$ & - & - & + & - & + & - & - \\
\hline
\end{tabular}


often multiple and embracing the entire spectrum of micro-organisms, remain basic components of the definition, and in this respect the patient in this report provides an example of AIDS. This is despite the fact that neither immunological evidence for an immune deficit nor evidence of human immunodeficiency virus (HIV) infection was obtained. The patient was in a high risk group and had repeated infections with evidence of bacterial, viral, and possibly protozoal infection at necropsy. He also had Kaposi's sarcoma which was widely disseminated. The Ziehl-Neelsen staining showed a disseminated mycobacterial infection, but in the absence of culture studies this cannot be classified. Mycobacterial infection is a recognised hazard for patients with AIDS and this is largely confined to the atypical group of organisms and most particularly Mycobacterium intracellularis complex (MAC). ${ }^{1-2}$ The patient in this report most probably had an infection of this type and the paucity of the associated histological changes supports this belief.

The preparation of polyclonal antibodies often entails the use of human serum and Freund's complete adjuvant. Human serum may include antibodies to mycobacteria if such an infection has occurred in the donor and an essential part of Freund's complete adjuvant is a Mycobacterium species. Cross reactivity between polyclonal antibodies prepared with human serum or Freund's complete adjuvant and tissues infected with mycobacterial species may therefore be anticipated. When substantial numbers of organisms are present, the reaction may be sufficient to cause false positivity for the reagent. Such an example occurred in our patient when antibody to FVIIIRA clearly labelled cells that, on the basis of other results, were macrophages. FVIIIRA characterises endothelial cells, and although reported in a range of other cells, ${ }^{8-10}$ has not occurred in macrophages. Macrophages in tissues from other patients did not give similar positivity.

Ziehl-Neelsen preparations showed that the stained cells contained vast numbers of mycobacteria similar to those seen in lepromatous leprosy. Skin biopsy specimens from patients with leprosy studied by outselves (personal observations) and others ${ }^{6}$ have given positive staining with polyclonal antibodies to lysozyme, $\alpha_{1}$-antitrypsin, cytokeratins, myoglobulin, S100 and FVIIIRA, which was attributed to contamination of the antisera with antibodies to mycobacteria. ${ }^{6}$ When these sera were purified the false positivity was lost. Our studies showed a similar result for a batch of antibody to FVIIIRA in a patient with a probably atypical mycobacterial infection. Purifying the antiserum by absorption with FVIIIRA abolished endothelial staining but had no effect when the eluted serum was used. The control with BSA, in which there was staining only with the absorbed serum, supported the conclusion that the absorption was complete. Mycobacteria were stained with both the test and the control sera after absorption with FVIIIRA, indicating that within these sera there was a component other than anti-FVIIIRA with an affinity for the organisms. The blocking of the mycobacterial staining by prior absorption with a Mycobacterium tuberculosis suspension provided further evidence for such a reagent. As mycobacterial antibodies cross react between the different species this result gives no indication of the species of organism within these tissues. These results, when compared with those in the patients with leprosy, clearly implicate antibodies to mycobacteria as the cause of the false positivity. The additional studies on the leprosy tissues, which showed false positivity when serum was used from a lepromatous patient and from a patient with a positive but not from a patient with a negative tuberculin skin test, as well as finding Mycobacterium butyricum within some of the antisera by radioimmunoassay and immunoblotting techniques, all provide further support for this conclusion. ${ }^{6}$ Our study also clearly shows that not all batches of a similar reagent, even from the same manufacturer, are similarly contaminated. This variation may follow from differences in techniques used in the preparation as well as in dilution procedures. False positivity may be avoided by prior testing of a batch of antibody on tissues infected with mycobacteria or by absorption purification of the antibody before use. Monoclonal antibodies should be exempt from this hazard, provided a direct peroxidase method is used. The possibility of mycobacterial antibodies within polyvalent antisera should alert the histopathologist to the potential of false positivity when examining tissues from patients with AIDS and other patients with disseminated mycobacterial infection. A further limitation of immunostaining that this study illustrates is in the use of both non-immune serum and BSA. As neither reagent is specific negative staining with these is not an adequate proof of the specificity of the antibody under test. $^{11}$

Advice was provided by $\mathbf{J}$ Morton and $\mathbf{R}$ Godfrey. Mrs R Hunt kindly typed the manuscript.

\section{References}

1 Horsburgh CR, Mason UG, Farhi DC, Iseman MD. Disseminated infection with Mycobacterium avium intracellulare: a report of 13 cases and a review of the literature. Medicine 1985;64:36-48.

2 Marchevsky A, Damsker B, Gribetz A, Tepper S, Geller SA. The spectrum of pathology of nontuberculous mycobacterial infections in open-lung biopsy specimens. Am J Pathol 1982;78:695-700.

3 Cohen RJ, Samuszuk MK, Busch D, Lagios M. Occult infections 
with $\mathbf{M}$ intracellulare in bone marrow biopsy specimens from patients with AIDS. New Engl J Med 1983;308:1475-6.

4 Gillin JS, Urmacher C, West R, Shike M. Disseminated Mycobacterium avium-intracellulare infection in acquired immunodeficiency syndrome mimicking Whipple's disease. Gastroenterology 1983;85:1187-91.

5 Strom RL, Gruninger RP. AIDS with Mycobacterium aviumintracellulare lesions resembling those of Whipple's disease. New Engl J Med 1983;309:1323-4.

6 Kahn HJ, Thorner P, Baumal R, et al. Immunohistochemical staining of macrophages in the skin lesions of leprosy: the role of antibody to mycobacteria in human serum and various polyclonal immune rabbit antisera. Histochem J 1985:17:1009-20.

7 Levy RM, Bredesen DE, Rosenblum ML. Neurological manifestations of the acquired immunodeficiency syndrome (AIDS): experience at UCSF and review of the literature. $J$
Neurosurg 1985;62:475-95.

8 Kindblom L. Factor VIII related antigen and mast cells. Acta Pathol Microbiol Immunol Scand 1982;90A:437-41.

9 Piovella F, Nalli G, Malamani GD et al. The ultrastructural localization of factor VIII antigen in human platelets, megakaryocytes and endothelial cells utilizing a ferritin-labelled antibody. Br J Haematol 1978;39:209-13.

10 Sinclair RA, Bourne CAJ. Factor VIII detected within glomerular mesangium. Lancet 1983;i:1448-9.

11 Heyderman E. Immunoperoxidase technique in histopathology: applications, methods, and controls. J Clin Pathol 1979;32:971-8.

Requests for reprints to: Dr PR Millard, Consultant Histopathologist, John Radcliffe Hospital, Level 1, Headington, Oxford OX3 9DU. 